\title{
The effects of the coastal environment on the atmospheric mercury cycle
}

Elizabeth G. Malcolm ${ }^{1}$ and Gerald J. Keeler

Air Quality Laboratory, University of Michigan, Ann Arbor, Michigan, USA

Matthew S. Landis

Office of Research and Development, Environmental Protection Agency, Research Triangle Park, North Carolina, USA

Received 29 October 2002; revised 5 February 2003; accepted 4 March 2003; published 21 June 2003.

[1] Atmospheric mercury (Hg) species were investigated on the east coast of Florida during June 2000. The site was impacted by air mass transport from the Atlantic Ocean and south Florida. Periods with atmospheric transport from the Atlantic were characterized by low concentrations of elemental gaseous $\mathrm{Hg}$ and inorganic divalent reactive gaseous mercury (RGM), demonstrating that the marine boundary layer was not a significant source of RGM to this coastal site as previous researchers have hypothesized. When anthropogenic impacts were observed at the site, indicated by elevated concentrations of gases including $\mathrm{HNO}_{3}$ and $\mathrm{SO}_{2}, \mathrm{RGM}$ concentrations had higher daytime maximums. Particulate phase $\mathrm{Hg}$ concentrations were higher than can be explained by sea spray alone, as determined by chemical analysis of the seawater, suggesting that gaseous $\mathrm{Hg}$ is diffusing into the sea-salt aerosol. Although atmospheric $\mathrm{Hg}$ concentrations were not elevated, the observed scavenging of $\mathrm{Hg}$ gases by sea-salt aerosols indicates that $\mathrm{Hg}$ may be rapidly cycled at the atmosphere-ocean interface between gaseous, aerosol, and oceanic forms. Deposition of aerosol enriched in $\mathrm{Hg}$ via this process may constitute a significant global mercury flux to the oceans. INDEX TERMS: 0305 Atmospheric Composition and Structure: Aerosols and particles (0345, 4801); 0312 Atmospheric Composition and Structure: Air/sea constituent fluxes (3339, 4504); 0365 Atmospheric Composition and Structure: Troposphere - composition and chemistry; 3339 Meteorology and Atmospheric Dynamics: Ocean/atmosphere interactions (0312, 4504); KEYWORDS: Atlantic, reactive gaseous mercury, particulate mercury, total gaseous mercury, marine boundary layer, sea salt

Citation: Malcolm, E. G., G. J. Keeler, and M. S. Landis, The effects of the coastal environment on the atmospheric mercury cycle, J. Geophys. Res., 108(D12), 4357, doi:10.1029/2002JD003084, 2003.

\section{Introduction}

[2] Most research on atmospheric mercury $(\mathrm{Hg})$ has focused on sources and deposition to terrestrial watersheds and freshwater lakes. Recently, several findings have highlighted the need for information on atmospheric $\mathrm{Hg}$ cycling in the marine environment. Fish consumption advisories have been expanded to include swordfish and tuna (Food and Drug Administration (FDA), An Important Message for Pregnant Women and Women of Childbearing Age Who May Become Pregnant About the Risks of Mercury in Fish, available at http://www.cfsan.fda.gov/ dms/admehg.html, 2001; Connecticut Department of Public Health, A Woman's Guide to Eating Fish safely, available at http://www.dph. state.ct.us/Publications/BCH/EEOH/pregwomen2.pdf, 2001) in addition to those for freshwater species. Recent measurements in the Arctic indicate that reactive halogen

\footnotetext{
${ }^{1}$ Now at Department of Geosciences, Princeton University.
}

species, released at polar sunrise, cause elemental gaseous mercury $\left(\mathrm{Hg}_{(g)}^{0}\right)$ oxidation and consequently large dry depositional fluxes of $\mathrm{Hg}$ to the snowpack [Schroeder et al., 1998; Lindberg et al., 2002]. Modeling studies of the Mediterranean [Hedgecock and Pirrone, 2001], measurements on the west coast of Ireland [Munthe et al., 2001], and a measurement campaign in Bermuda [Mason et al., 2001] have suggested that marine-derived halogen compounds, in temperate and tropical regions, could oxidize $\mathrm{Hg}_{(g)}^{0}$ to inorganic divalent reactive gaseous mercury (RGM), and therefore be a significant source to local or regional deposition.

[3] Three major forms of $\mathrm{Hg}$ exist in the atmosphere: $\mathrm{Hg}_{(g)}^{0}, \mathrm{RGM}$, and particulate phase $\left(\mathrm{Hg}_{(p)}\right) \cdot \mathrm{Hg}_{(g)}^{0}$ typically comprises over $95 \%$ of $\mathrm{Hg}$ in the atmosphere and is relatively inert, with a lifetime currently estimated to be 6 months to 1 year [Lin and Pehkonen, 1999]. Consequently, $\mathrm{Hg}_{(g)}^{0}$ can be distributed on a global scale. RGM (e.g., $\mathrm{HgCl}_{2}$ and $\left.\mathrm{HgBr}_{2}\right)$ is water-soluble and reactive and has a high dry deposition velocity, often compared to that of nitric acid $\left(1-5 \mathrm{~cm} \mathrm{~s}^{-1}\right)$ [Environmental Protection Agency (EPA), 1998; Malcolm and Keeler, 2002]. $\mathrm{Hg}_{(p)}$ is also readily 
deposited by wet or dry deposition mechanisms. All of these $\mathrm{Hg}$ species can also be present in cloud water and raindrops [Lin and Pehkonen, 1999]. The presumed importance of the marine environment in all the studies previously cited is that marine halogen compounds oxidize $\mathrm{Hg}$ from $\mathrm{Hg}_{(g)}^{0}$ to a more easily deposited form such as RGM, thereby increasing local and regional deposition.

[4] In the Arctic it was observed that from polar sunrise, after weeks of darkness, to snowmelt, $\operatorname{Hg}_{(g)}^{0}$ concentrations dramatically dropped, as $\mathrm{RGM}$ and $\mathrm{Hg}_{(p)}$ concentrations rose [Lindberg et al., 2002]. This phenomenon coincides with tropospheric ozone depletion, which is caused by reactions with photochemically produced gaseous radical $\mathrm{Br}$ species. Oxidation by these radicals has been hypothesized to cause the change in $\mathrm{Hg}$ speciation. The $\mathrm{RGM}$ and $\mathrm{Hg}_{(p)}$ are dry deposited to the snowpack, and the $\mathrm{Hg}$ is either photoreduced and fluxes back into the atmosphere or enters the Arctic ecosystem during snowmelt via runoff.

[5] Hedgecock and Pirrone [2001] developed a chemical box model to investigate the role of halogen chemistry on $\mathrm{Hg}$ in the Mediterranean region. In their model the sea-salt concentration is kept constant, and $\mathrm{Hg}$ species are removed by dry deposition. They concluded that the sea-salt aerosols, which contain a significant aqueous phase, act as reactors for the oxidation of $\mathrm{Hg}_{(g)}^{0}$ to $\mathrm{HgCl}_{2(g)}$. The final steady state $\mathrm{HgCl}_{2(\mathrm{~g})}$ concentration of 4.7 picograms per cubic meter $\left(\mathrm{pg} \mathrm{m}^{-3}\right)$, although quite low compared to measurements near anthropogenic sources, could theoretically comprise a significant portion of RGM in remote marine environments.

[6] Munthe et al. [2001] recently made measurements of RGM at a remote location on the west coast of Ireland. Concentrations measured averaged $35 \mathrm{pg} \mathrm{m}^{-3}$, higher than measurements made simultaneously at rural locations in southern Sweden. To investigate whether the concentrations could be caused by oxidation of $\mathrm{Hg}_{(g)}^{0}$ by $\mathrm{BrO}$, they estimated a reaction rate from Arctic measurements during $\mathrm{Hg}_{(\mathrm{g})}^{0}$ depletion events and modeled a diurnal maximum of $25 \mathrm{pg} \mathrm{m}^{-3}$ for this reaction [Iverfeldt et al., 2001].

[7] Lastly, Mason et al. [2001] made RGM measurements over the Atlantic, near Bermuda, using a cation exchange filter [Prestbo and Bloom, 1996], and found average concentrations of $280 \pm 260 \mathrm{pg} \mathrm{m}^{-3}$, which are surprisingly high for samples including both daytimes and nighttimes, even compared to measurements from anthropogenic source areas. The authors suggest that the marine boundary layer (MBL) may be a large source of RGM not only over the open ocean but also in coastal marine environments [Sheu and Mason, 2001].

[8] In light of the recent marine fish advisories and the fact that $\sim 80 \%$ of the world's population lives along coasts, it is critically important to determine whether the MBL is a large source of RGM. Therefore the objectives of this study were to: (1) characterize $\mathrm{Hg}$ concentrations and variations along the Atlantic coast of south Florida, (2) determine the role of marine air as a source of $\mathrm{Hg}_{(g)}^{0}, \mathrm{RGM}$, and $\mathrm{Hg}_{(p)}$, and (3) investigate $\mathrm{Hg}$ transformations in the MBL. This is the first study of RGM in the MBL with continuous hourly samples over multiple weeks. Results of this study will be useful for the parameterization and verification of regional and global $\mathrm{Hg}$ models, as well as for identifying major sources of $\mathrm{Hg}$ to marine fish and biota.

\section{Sampling Site}

[9] The sampling site was located in Pompano Beach, Florida $\left(26^{\circ} 14^{\prime} 17^{\prime \prime} \mathrm{N}, 80^{\circ} 05^{\prime} 39^{\prime \prime} \mathrm{W}\right)$, located adjacent to the Atlantic Ocean, $\sim 20 \mathrm{~km}$ northeast of Fort Lauderdale and $50 \mathrm{~km}$ northeast of Miami in a mostly residential and light commercial area. Sampling was performed atop an Environmental Protection Agency (EPA) mobile laboratory $\sim 4 \mathrm{~m}$ above the ground. The mobile laboratory was located in a parking lot $\sim 150 \mathrm{~m}$ from the shoreline and had mostly open fetch to the water interrupted only by a few palm trees and some dune brush. The intensive sampling campaign was conducted from 3 to 28 June, 2000.

\section{Methods}

[10] Collection and analysis of $\mathrm{Hg}_{(g)}^{0}$ and RGM was accomplished using two identical automated systems combining the analytical capability of the Tekran (Tekran, Inc., Toronto, Canada) model 2537A cold vapor atomic fluorescence spectrometer (CVAFS) and a Tekran model 1130 speciation unit [Landis et al., 2002]. The 1130 systems were configured to collect 1-hour integrated RGM samples onto $\mathrm{KCl}$-coated quartz annular denuders at $10 \mathrm{~L} \mathrm{~min}^{-1}$. During the 1-hour RGM sampling period, 5-min $\operatorname{Hg}_{(g)}^{0}$ samples were continuously quantified by the 2537A analyzer. After the 1-hour sampling period the 1130 system was flushed with $\mathrm{Hg}$-free air, and the $\mathrm{Hg}$ collected on the quartz denuder was thermally decomposed into the $\mathrm{Hg}$-free airstream and subsequently quantified as $\operatorname{Hg}_{(g)}^{0}$. The two systems were offset from each other by 1 hour to obtain continuous data uninterrupted by the RGM analysis cycle. Periods with no measurements, during either system calibrations or problems such as power interruptions, are noted. The 2537A analyzers were calibrated weekly using the internal $\mathrm{Hg}$ permeation tubes. A portable Tekran 2505 primary mercury calibration unit was used to calibrate each analyzer's permeation tube at the beginning of the study and to provide weekly standard addition checks. KCl-coated annular denuders were recoated and changed weekly. Thermal desorption of $\mathrm{KCl}$-coated denuders for RGM determination has been extensively evaluated by Landis et al. [2002]. In their laboratory investigations the capture efficiency of a known concentration of $\mathrm{HgCl}_{2}$ was $>97 \%$. In field measurements, precision determined by collocated samples was $15 \%$, and breakthrough onto a backup denuder for samples of $<5$ hours was $<6 \%$. The method detection limits (MDL) for $\mathrm{Hg}_{(\mathrm{g})}^{0}$ and $\mathrm{RGM}$ for the system configuration (5-min $\mathrm{Hg}_{(g)}^{0}$ and 1-hour RGM sampling) were 0.1 nanograms per cubic meter $\left(\mathrm{ng} \mathrm{m}^{-3}\right)$ and $6 \mathrm{pg} \mathrm{m}^{-3}$, respectively [Landis et al., 2002].

[11] During this study a negative $\mathrm{Hg}_{(p)}$ sampling artifact was discovered that results in higher concentrations for short-duration (4-hour) than longer-duration (12-hour) samples [Malcolm, 2002]. The shorter-duration samples were found to be more accurate, and less prone to sampling artifacts, and thus the 4-hour samples are reported in this manuscript. Since this artifact problem was not anticipated before the study, 4-hour samples were only collected on 
13 days of the study and not during nighttime periods. $\operatorname{Hg}_{(p)}$ was sampled and analyzed using the EPA IO-5 method. $\mathrm{Hg}_{(p)}$ was measured in two distinct size groups, particulate matter $(\leq 2.5 \mu \mathrm{m})\left(\mathrm{PM}_{2.5}\right)$ and $\mathrm{PM}_{10}(\leq 10 \mu \mathrm{m})$, using Teflon ${ }^{\mathrm{TM}}$-coated cyclones (URG, Corp., Chapel Hill, North Carolina) onto 47-mm Pallflex quartz filters. $\mathrm{Hg}_{(p)}$ was extracted in Teflon bombs by microwave digestion in nitric acid and analyzed in a class 100 clean room by CVAFS. Duplicate analyses were done for $90 \%$ of samples giving a mean difference of $5.6 \mathrm{pg}$ filter ${ }^{-1}$ for $\mathrm{PM}_{2.5}$ and $5.5 \mathrm{pg}$ filter ${ }^{-1}$ for $\mathrm{PM}_{10}$. This difference corresponds to a concentration of $\sim 1.4 \mathrm{pg} \mathrm{m}^{-3}$ for a $\mathrm{PM}_{10}$ sample and $0.7 \mathrm{pg} \mathrm{m}^{-3}$ for a $\mathrm{PM}_{2.5}$ sample. Sixteen field blanks were collected by placing a filter in the sampling apparatus with the pumps off for $2 \mathrm{~min}$. The mean for the blanks was $3.4 \mathrm{pg} \mathrm{filter}^{-1}$, or $\sim 1 \mathrm{pg} \mathrm{m}^{-3}$ for a $\mathrm{PM}_{10}$ sample, and $1.7 \mathrm{pg} \mathrm{m}^{-3}$ for a $\mathrm{PM}_{2.5}$ sample. The MDL, calculated as 3 times the standard deviation of the field blanks, was $17 \mathrm{pg}$ filter $^{-1}$ or $\sim 4.3$ pg $\mathrm{m}^{-3}$.

[12] Acidic and basic aerosols and gases were sampled using a dual annular denuder and dual filter method [Keeler et al., 1991] (EPA method IO-4.2), which were extracted and analyzed by ion chromatography on a Dionex DX-600 system. The first denuder was coated with sodium carbonate to collect the gases $\mathrm{SO}_{2}, \mathrm{HNO}_{3}, \mathrm{HONO}, \mathrm{HCl}$, and $\mathrm{HBr}$. The second, a phosphorous acid denuder [Perrino and Gherardi, 1999], sampled $\mathrm{NH}_{3}$. Aerosols were sampled on a $0.4-\mu \mathrm{m}$ Teflon filter with a sodium-carbonate-impregnated backup filter for determination of $\mathrm{SO}_{4}^{2-}, \mathrm{NO}_{3}^{-}, \mathrm{NO}_{2}^{-}, \mathrm{Cl}^{-}, \mathrm{Br}^{-}$, and $\mathrm{NH}_{4}^{+}$.

[13] Additional particulate matter samples were collected using a Versatile Air Pollutant Sampler (VAPS) (URG, Corp., Chapel Hill, North Carolina). The VAPS is a modified dichotomous sampler that simultaneously collects two fine fraction $(<2.5 \mu \mathrm{m})$ samples and one coarse fraction $(2.5-10 \mu \mathrm{m})$ sample from a single airstream using a virtual impactor [Pinto et al., 1998]. The fine and coarse samples were collected at flow rates of $15 \mathrm{~L} \mathrm{~min}^{-1}$ and $2 \mathrm{~L} \mathrm{~min}^{-1}$, respectively. One fine sample was collected on prebaked quartz filters for elemental carbon (EC) and organic carbon (OC) analysis using thermal optical reflectance analysis [Birch and Cary, 1996]. The second fine and the coarse sample were collected onto Teflon filters for gravimetric determination of particulate mass. Filter weights were obtained with a microbalance in a temperature- and humidity-controlled environment.

[14] Ozone measurements were made using an UV photometric analyzer (Thermo Environmental Instruments, Inc., Franklin, Massachusetts, model 49C). This analyzer was calibrated in the field on a weekly basis using a dynamic dilution calibration unit equipped with an $\mathrm{O}_{3}$ generator and a certified photometer (Dasibi Corp., Glendale, California, 5009-CP). Meteorological measurements were made from a 10-m telescoping tower, and solar insolation measurements were made using an Epply PSP radiometer.

[15] Clean techniques were employed throughout the study. Filter packs were loaded and unloaded in a High Efficiency Particulate Air (HEPA) filtered hood for mercury and carbon and in an acid-gas- and ammonia-free glove bag for acid aerosols. In addition, particle-free gloves were worn at all times, and samples and sampling equipment were stored and transported in new Zip Lock ${ }^{\mathrm{TM}}$ bags. All filter packs and petri dishes used for $\mathrm{Hg}$ were acid-cleaned with $\mathrm{HCl}$ and $\mathrm{HNO}_{3}$, in a procedure described by Landis and Keeler [1997]. All cyclones were rinsed five times with ASTM type I water and dried in the HEPA-filtered hood before and during the study.

[16] The Wilcoxon rank-sum test [Cody and Smith, 1997] was used for comparisons of concentrations between two different time periods. This nonparametric statistical method was chosen since concentration distributions were often significantly different from normal and the two sample groups being compared had unequal variances. The probability that the groups are equal in concentration, $p$, is reported. For $\mathrm{Hg}_{(p)}$ the three samples collected on 1 day were averaged for a daily concentration before other statistical calculations, unless otherwise noted.

\section{Meteorology}

[17] Strong solar radiation and high temperatures often dominate the meteorology in south Florida causing high convection, local thunderstorms, and sea breeze/land breeze circulations. These meteorological events in turn affect the transport and deposition of pollutants on the peninsula by creating a deep mixed layer at the surface, heavy rain, and often diurnally varying wind directions. These factors make understanding and modeling of atmospheric pollutants extremely difficult. For example, sea breeze circulations can form along a coast owing to the differential heating of land and water, causing onshore flow at the surface and possibly a return offshore flow aloft. The depth of this circulation can penetrate over $20 \mathrm{~km}$ inland [Ahrens, 1994]. At night, winds often weaken, and the faster cooling of land can set up the opposite circulation with offshore winds at the surface, termed a land breeze. These circulations can cause mixing of air masses from land and over water. Since large populations live along the coast of Florida, this can result in the mixing of polluted urban air with cleaner, marine air. As a consequence, this mixing has been found to bring pollutants transported offshore back onshore during a sea breeze, causing elevated ozone along the southeast coast of Florida (K. Larson, Broward County Air Division, personal communication, 2000).

[18] During this study in June 2000, Pompano Beach experienced the dynamic conditions described above as well as a period of prolonged constant onshore flow. The first 6 days of the study ( $3-8$ June) were characterized by easterly or southeasterly winds during the day, shifting to lighter westerly or northwesterly winds at night $\left(<2 \mathrm{~m} \mathrm{~s}^{-1}\right)$. The shift to nighttime conditions typically occurred between 1800 and 0100 local time (LT). The shift back to the easterly daytime flow usually occurred between 0700 and 1000 LT.

[19] On 9 June this pattern changed when a high-pressure system developed off the east coast of Florida, resulting in relatively constant, easterly, synoptic flow. This onshore flow was characterized by a very constant wind direction of $100^{\circ}$ to $120^{\circ}$ and speed of $1-6 \mathrm{~m} \mathrm{~s}^{-1}$. Unlike onshore flows during sea breeze circulations, this larger-scale synoptic flow was expected to transport "clean" marine air to the site, unaffected by emission sources in Florida. These conditions lasted until $\sim 2: 00$ on 19 June, when winds weakened to $<2 \mathrm{~m} \mathrm{~s}^{-1}$ and were highly variable in direction. 


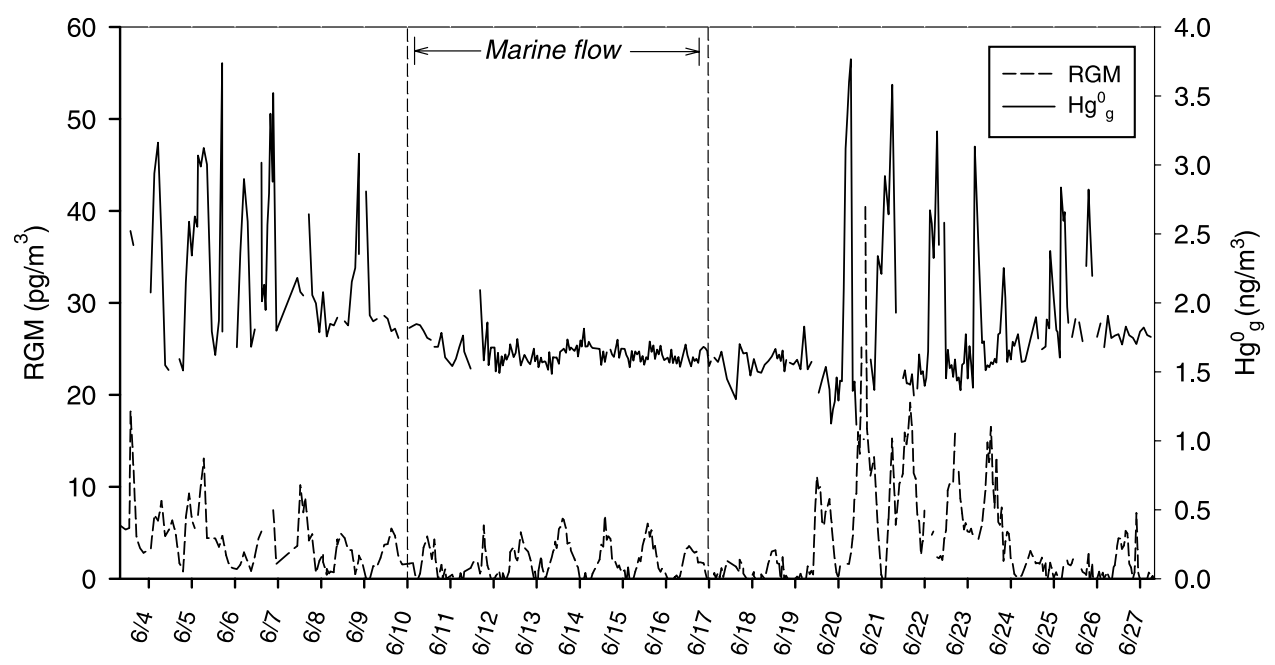

Figure 1. Concentrations of ambient $\mathrm{Hg}$ gases at Pompano Beach, Florida, for the study period. From 10-17 June 2000 there was synoptic onshore (marine) flow to the site. Before and after this period, wind direction was more variable, including flow from the ocean and Florida.

This began a return to the diurnal variations in wind present during the beginning of the study. The only subsequent night on which flow did not shift to the west was 26 June, when easterly flow continued for a 40-hour period.

[20] Over the course of the 26-day study, precipitation occurred at the Pompano Beach site on 12 days. Most of these were isolated convective storms lasting $<1$ hour. The maximum measured precipitation rate was $8.9 \mathrm{~mm}$ in a 5-min period. Precipitation was often associated with strong and variable winds that interrupted more regular wind patterns described in this section.

[21] Wet deposition of $\mathrm{Hg}$ has previously been studied in south Florida [Dvonch et al., 1999, 1998; Guentzel et al., 1995; Landing et al., 1995]. These studies reported that the highest concentrations and deposition of $\mathrm{Hg}$ are observed in the May-September time period. For the June 2000 period the volume-weighted mean $\mathrm{Hg}$ precipitation concentration at the site was $10.9 \mathrm{ng} \mathrm{L}^{-1}(\mathrm{n}=12)$ and the total deposition of $\mathrm{Hg}$ was $1.1 \mathrm{\mu g} \mathrm{m}^{-2}$ for the 23 days studied.

[22] For purposes of evaluating the MBL as a source of oxidized mercury the period of strong, onshore, synoptic flow from 10 to 17 June was identified as bringing "clean" marine air to the site and represented marine conditions. The first and last day of easterly synoptic flow were excluded to avoid any possible effects from the previous conditions or transitions in meteorology. This 10 -day period is referred to as the "marine regime." For comparison the remainder of the study (3-8 June and 19-26 June) was classified as a "mixed" regime, during which there was often a marine signal mixed with air masses influenced by the urbancontinental sources of the Florida peninsula.

\section{Results}

[23] For the study duration, $\operatorname{Hg}_{(g)}{ }^{0}$ ranged from 1.0 to $3.8 \mathrm{ng} \mathrm{m}^{-3}$ (Figure 1). During marine conditions (10$17 \mathrm{June}), \mathrm{Hg}_{(\mathrm{g})}^{0}$ concentrations were relatively constant, with a mean \pm standard deviation of $1.6 \pm 0.06 \mathrm{ng} \mathrm{m}^{-3}$ and a maximum of $1.8 \mathrm{ng} \mathrm{m}^{-3}$. During the mixed meteorological conditions (3-9 June and 18-27 June), $\mathrm{Hg}_{(g)}^{0}$ concentra- tions were much more variable and significantly higher ( $p=0.0002)$, averaging $2.0 \pm 0.4 \mathrm{ng} \mathrm{m}^{-3}$ with a maximum of $3.8 \mathrm{ng} \mathrm{m}^{-3}$. Concentrations during this period were often elevated at night, usually corresponding to shifts in winds, and are examined in greater detail in section 6.

[24] Over the study period, RGM generally exhibited a diurnal pattern with a daytime peak between 1100 and 1700 LT (Figure 1). At night, concentrations nearly always were below the MDL of $6 \mathrm{pg} \mathrm{m}^{-3}$. During the marine regime, concentrations were mainly below our MDL $(1.6 \pm$ $\left.1.4 \mathrm{pg} \mathrm{m}^{-3}\right)$ with low daytime maximums $\left(2-7 \mathrm{pg} \mathrm{m}^{-3}\right)$. During the mixed regime, daytime peaks were often higher, ranging from 3 to $40 \mathrm{pg} \mathrm{m}^{-3}$, and the overall average, $4.9 \pm$ $4.0 \mathrm{pg} \mathrm{m}^{-3}$, was significantly higher $(p=0.001)$.

[25] On 7 days of the study, three 4-hour $\mathrm{Hg}_{(p)}$ samples were collected from 0800 to $1200 \mathrm{LT}, 1200$ to $1600 \mathrm{LT}$, and 1600 to 2000 LT. On 6 of the study days, one 4-hour $\operatorname{Hg}_{(p)}$ sample was collected from 1200 to 1600 LT. Owing to the small number of samples collected, and the possibility that they are not entirely free from artifact, the ability to extrapolate from these samples is limited. However, these data provide an important glimpse of coastal $\mathrm{Hg}_{(p)}$ concentrations and behavior, especially if previous measurements were subject to larger uncertainties. Concentrations of $\mathrm{PM}_{2.5}$ samples ranged from $<0.8$ to 11.0 (including all 4-hour samples), with a mean \pm standard deviation of $3.5 \pm$ $2.8 \mathrm{pg} \mathrm{m}^{-3}$. Concentrations of $\mathrm{PM}_{10}$ samples, ranged from 3.7 to 40.6 , with a mean \pm standard deviation of $17.9 \pm$ $12.8 \mathrm{pg} \mathrm{m}^{-3}$ (Figure 2). No consistent diurnal trend was observed. The $\mathrm{Hg}_{(p)}$ concentrations during marine flow were $6.3 \pm 4.4$ for $\mathrm{PM}_{2.5}$ and $25.0 \pm 12.5$ for $\mathrm{PM}_{10}(n=$ 3 days). The $\mathrm{Hg}_{(p)}$ concentrations for mixed flow were $1.7 \pm$ 0.7 for $\mathrm{PM}_{2.5}$ and $15.2 \pm 9.7$ for $\mathrm{PM}_{10}(n=3$ days $)$. The sample size is insufficient to determine whether there is a significant difference between the two periods or to speculate how representative these samples may be to typical conditions.

[26] Under the two types of meteorological conditions (marine and mixed), concentrations of most species measured with anthropogenic or land-based origins also differed 


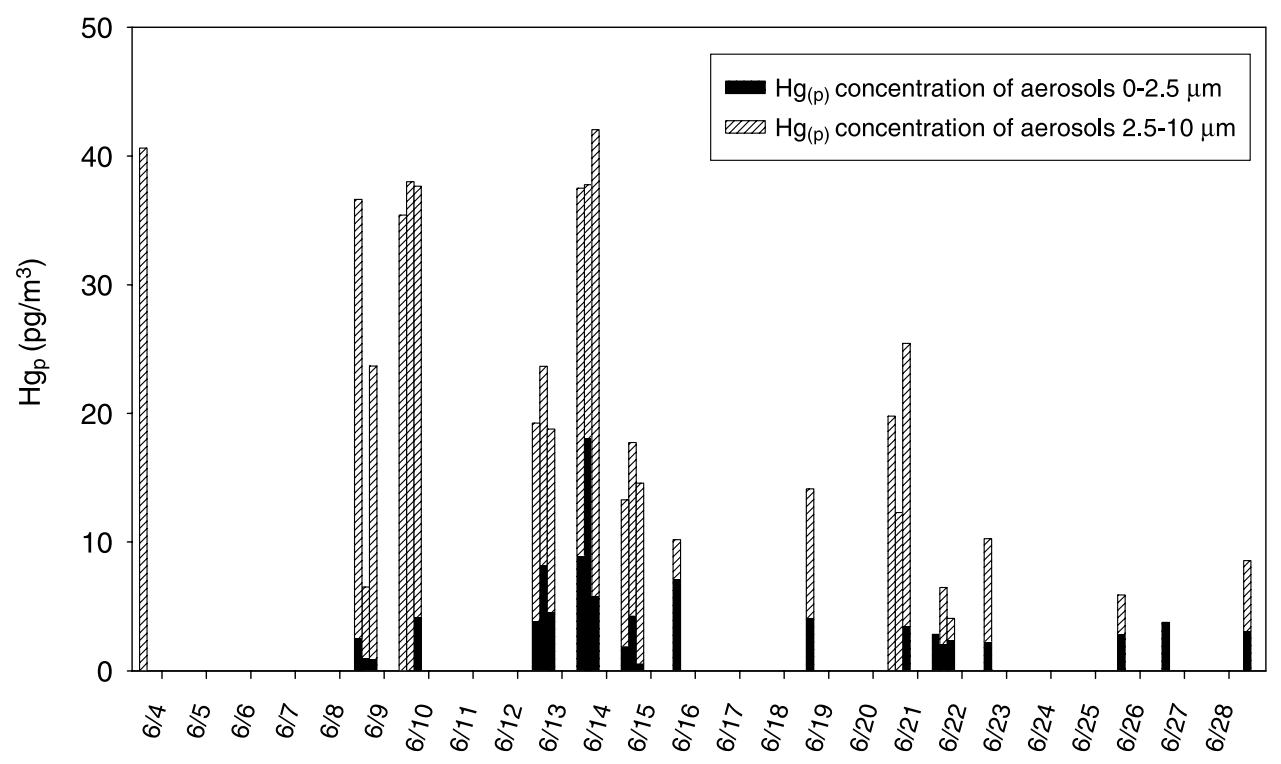

Figure 2. Concentrations of particulate phase mercury $\left(\operatorname{Hg}_{(p)}\right)$ in the (shaded bars) $0-2.5-\mu \mathrm{m}$ and (hatched bars) 2.5-10- $\mathrm{m}$ size ranges. Samples were collected at 0800-12:00 LT, 1200-1600 LT, or 1600-2000 LT. Three samples were collected each day on 8, 9, 12, 13, 14, 20, and 21 June. Only one sample was collected each day on $3,15,18,22,25,26$, and 28 June.

(Table 1). Concentrations were typically low and relatively constant during the synoptic marine flow and were generally higher and much more variable under mixed flow (Table 1). This is due to the added and variable influence of transport from Florida (and perhaps the Gulf of Mexico) to the site. For example, concentrations of the gases $\mathrm{HNO}_{3}$, $\mathrm{HONO}$ and $\mathrm{SO}_{2}$, and $\mathrm{EC}$ and $\mathrm{OC}$ were significantly higher during mixed flow conditions. Potential sources of these species in Florida include power plants, boilers, and automobiles. OC can also have biogenic sources within Florida.

[27] Aerosol sodium and chloride concentrations were typically high for both regimes, demonstrating the large and relatively constant influence of the MBL on the site. Further evidence of mixing between anthropogenic gases from continental sources with marine air during the "mixed" conditions is given by the ratio of aerosol chloride to sodium. It has been demonstrated that when acid gases such as $\mathrm{HNO}_{3}$ or $\mathrm{H}_{2} \mathrm{SO}_{4}$ contact sea-salt aerosols, the seasalt chloride is replaced by the acid's anion $\left(\mathrm{NO}_{3}{ }^{-}\right.$or $\mathrm{SO}_{4}{ }^{2-}$ ), and the chlorine is depleted from the aerosol, leaving as $\mathrm{HCl}$ gas [Volpe et al., 1998]. Consequently, the molar ratio of chloride/sodium in the MBL with anthropogenic influence is much less than that in the remote MBL. For pure seawater, the ratio is 0.85 . During the marine regime this ratio in the aerosol averaged 0.7 , and during the mixed regime it averaged 0.3 . This is consistent with higher concentrations of $\mathrm{HNO}_{3}$ and $\mathrm{H}_{2} \mathrm{SO}_{4}$ during the mixed regime, which would have caused $\mathrm{Cl}^{-}$depletion and release of $\mathrm{HCl}$.

\section{Discussion}

\subsection{The Marine Boundary Layer as a Source of $\mathbf{H g}$}

[28] To evaluate the importance of the MBL as a source of $\mathrm{Hg}$ for the study and in general, $\mathrm{Hg}$ concentrations measured at this site were compared to measurements from other types of locations (Table 2). During this study, measurements were also made in the Florida Everglades (F. J. Marsik, et al., personal communication, 2003) as part of the Florida Everglades Dry Deposition Study. Measurements from summertime sampling campaigns at two locations in Michigan [Dvonch et al., 2001] are also presented in Table 2. Dexter, Michigan, is a rural location with no local point sources. Approximately $70 \mathrm{~km}$ to the east of Dexter is the industrial city of Detroit, with $\mathrm{Hg}$ point sources including incinerators, coal-fired power plants,

Table 1. Mean and Standard Deviation of Measured Parameters During Marine (10-17 June) or Mixed (3-8 June and 19-26 June) Flow Conditions ${ }^{\text {a }}$

\begin{tabular}{|c|c|c|c|}
\hline Parameter & Marine & Mixed & $p$ \\
\hline $\begin{array}{l}\mathrm{Hg}_{(g)}^{0}, \mathrm{ng} \mathrm{m}^{-3} \\
\mathrm{RGM}^{-3} \mathrm{pg} \mathrm{m}^{-3} \\
\mathrm{Hg}_{(p)} \mathrm{PM}_{2.5}{ }^{\mathrm{b}} \mathrm{pg} \mathrm{m}^{-3} \\
\mathrm{Hg}_{(p)} \mathrm{PM}_{10},{ }^{\mathrm{b}} \mathrm{pg} \mathrm{m}^{-3}\end{array}$ & $\begin{array}{l}\text { Mercury } \\
1.6 \pm 0.06 \\
1.6 \pm 1.5 \\
6.3 \pm 4.4 \\
25.0 \pm 12.5\end{array}$ & $\begin{array}{c}2.0 \pm 0.4 \\
4.8 \pm 3.9 \\
1.7 \pm 0.7 \\
15.2 \pm 9.7\end{array}$ & $\begin{array}{c}0.0002 \\
0.001\end{array}$ \\
\hline $\begin{array}{l}\mathrm{O}_{3}, \mathrm{ppb} \\
\mathrm{HNO}_{3}, \mathrm{ppb} \\
\mathrm{HCl}, \mathrm{ppb} \\
\mathrm{HONO}, \mathrm{ppb} \\
\mathrm{SO}_{2}, \mathrm{ppb}\end{array}$ & $\begin{array}{c}\text { Gases } \\
25 \pm 7 \\
0.03 \pm 0.03 \\
0.20 \pm 0.16 \\
0.03 \pm 0.02 \\
0.27 \pm 0.30\end{array}$ & $\begin{array}{c}30 \pm 9 \\
0.32 \pm 0.37 \\
0.36 \pm 0.26 \\
0.16 \pm 0.19 \\
0.7 \pm 0.6\end{array}$ & $\begin{array}{c}0.09 \\
<0.0001 \\
0.02 \\
<0.0001 \\
0.001\end{array}$ \\
\hline $\begin{array}{l}\mathrm{SO}_{4}^{2-} \text {, nanomoles } \mathrm{m}^{-3} \\
\mathrm{NH}_{4}^{+} \text {, nanomoles } \mathrm{m}^{-3} \\
\mathrm{Na}^{+} \text {, nanomoles } \mathrm{m}^{-3} \\
\mathrm{Cl}^{-} \text {, nanomoles } \mathrm{m}^{-3} \\
\mathrm{Cl}^{-} / \mathrm{Na}^{+} \\
\text {Organic carbon, } \mu \mathrm{g} \mathrm{m}^{-3} \\
\text { Elemental carbon, } \mu \mathrm{g} \mathrm{m}^{-3}\end{array}$ & $\begin{array}{c}\text { Aerosols } \\
13 \pm 4 \\
11 \pm 3 \\
35 \pm 11 \\
26.1 \pm 9.4 \\
0.76 \\
0.7 \pm 0.1 \\
0.06 \pm 0.03\end{array}$ & $\begin{array}{c}18 \pm 15 \\
22 \pm 21 \\
24 \pm 21 \\
9.9 \pm 12.3 \\
0.33 \\
1.5 \pm 0.9 \\
0.24 \pm 0.24\end{array}$ & $\begin{array}{c}0.09 \\
0.07 \\
0.008 \\
<0.0001\end{array}$ \\
\hline
\end{tabular}

${ }^{\mathrm{a}} p$ value is result of one-tailed Wilcoxin test for significant difference.

${ }^{\mathrm{b}} \mathrm{Hg}_{(p)}$ was sampled for 3 days during this condition. 
Table 2. Comparisons of Atmospheric Mercury Concentration Means, Standard Deviations, and Maximums ${ }^{\mathrm{a}}$

\begin{tabular}{|c|c|c|c|c|c|}
\hline & Marine & Mixed & Everglades, Florida & Detroit, Michigan & Dexter, Michigan \\
\hline \multicolumn{6}{|l|}{$\mathrm{Hg}_{\mathrm{g}}{ }^{0}, \mathrm{ng} \mathrm{m}^{-3}$} \\
\hline Mean and SD & $1.6 \pm 0.06$ & $2.0 \pm 0.4$ & $1.5 \pm 0.1$ & $2.2 \pm 3.2$ & $1.5 \pm 0.1$ \\
\hline Maximum & 18 & 3.2 & 2.4 & 40 & 1.9 \\
\hline \multicolumn{6}{|l|}{$\mathrm{RGM} \mathrm{pg} \mathrm{m}^{-3}$} \\
\hline Mean and SD & $1.6 \pm 1.4$ & $4.9 \pm 4.0$ & $1.2 \pm 1.6$ & $9.6 \pm 10$ & $4.3 \pm 4.5$ \\
\hline Maximum & 6.9 & 40 & 14 & 66 & 38 \\
\hline \multicolumn{6}{|l|}{$\mathrm{Hg}_{p} \mathrm{PM}_{25}, \mathrm{pg} \mathrm{m}^{-3}$} \\
\hline Mean and SD & $6.3 \pm 4.4$ & $1.6 \pm 0.7$ & $4.7 \pm 2.4$ & $23 \pm 28$ & $6.6 \pm 3.5$ \\
\hline Maximum & 11.0 & 2.4 & 8.5 & 134 & 11 \\
\hline Dates & $10-17$ June 2000 & $3-8$ and $19-26$ June 2000 & $6-20$ June 2000 & $16-30$ July 2000 & 1-12 May 2001 \\
\hline Reference & this study & this study & $\begin{array}{l}\text { F. J. Marsik et al. } \\
\text { (personal communication, 2003) }\end{array}$ & Dvonch et al. [2001] & Dvonch et al. [2001] \\
\hline
\end{tabular}

${ }^{\mathrm{a}}$ For this study and those at other locations. $\mathrm{Hg}_{(p)}$ was sampled for 3 days each under marine and mixed conditions.

and iron and steel manufacturing. Concentrations of $\mathrm{Hg}$ measured during marine flow are similar to those measured in other locations without major anthropogenic influence, corroborating our hypothesis that the MBL is not a source of elevated atmospheric $\mathrm{Hg}$ relative to other sources.

[29] Concentrations of RGM were generally lower than those reported at other marine locations by Munthe et al. [2001] (mean $=35 \mathrm{pg} \mathrm{m}^{-3}$ ) and especially by Mason et al. [2001] (mean $=280 \mathrm{pg} \mathrm{m}^{-3}$ ). The denuder method we employed for RGM has been extensively evaluated [Landis et al., 2002] and is currently being widely used by other research groups [Lindberg et al., 2002; Sprovieri et al., 2002; Temme et al., 2003]. Our continuous 1-hour integrated RGM measurements over a 25-day period using the automated annular denuder methodology for this study are the most comprehensive to date for a marine location and therefore are likely to be more representative of typical MBL concentrations.

\subsection{Elemental Gaseous Mercury}

[30] The mean concentration of $\operatorname{Hg}_{(g)}^{0}$ measured during marine flow $\left(1.6 \mathrm{pg} \mathrm{m}^{-3}\right)$ is similar to that measured on cruises on the Atlantic Ocean [Lamborg et al., 1999; Mason et al., 2001] of $1.6 \pm 0.09$ and $2.0 \pm 0.4 \mathrm{ng} \mathrm{m}^{-3}$, respectively. These concentrations are also similar to those measured in the wintertime Arctic $\left(1.6-1.8 \mathrm{ng} \mathrm{m}^{-3}\right)$ [Lindberg et al., 2002]. This suggests that $\mathrm{Hg}_{(g)}^{0}$ levels measured during marine flow in this study are close to what can be considered a global background concentration.

[31] The main sources of $\operatorname{Hg}_{(g)}^{0}$ are typically direct emission from anthropogenic and natural sources or long-range transport of this globally dispersed gas. It was expected that concentrations of $\mathrm{Hg}_{(g)}^{0}$ would have little variation and the variation that was present would coincide with changes in wind direction. Spikes in the $\operatorname{Hg}_{(g)}^{0}$ concentration were observed that corresponded to shifts in wind direction from marine (easterly) to westerly or northwesterly. Examples of this can be seen in Figure 3. In the early hours of 19 June the period of prolonged easterly flow ended, and the wind was low $\left(<2 \mathrm{~m} \mathrm{~s}^{-1}\right)$ with variable direction. During the day of 19 June, onshore flow resumed. Throughout 19 June, $\mathrm{Hg}_{(g)}^{0}$ concentrations remained similar to those of the previous nine days ranging between 1.1 and $1.6 \mathrm{ng} \mathrm{m}^{-3}$. On 20 June, however, between 0300 and 0700 LT, the wind speed again dropped $\left(<1.2 \mathrm{~m} \mathrm{~s}^{-1}\right)$, and the direction became variable $\left(240^{\circ}\right.$ to $\left.80^{\circ}\right)$. During this period the $\mathrm{Hg}_{(g)}^{0}$ concentration rose to $3.8 \mathrm{ng} \mathrm{m}^{-3}$, suggesting that a $\mathrm{Hg}_{(g)}^{0}$ source to the northwest was affecting the site. In the following 24 hours the pattern was repeated with low $\mathrm{Hg}_{(g)} 0$ concentrations during the day with marine flow and higher concentrations at night after the wind direction shifted to come from land. On this night, however, the shift in wind direction was more constant at $290^{\circ}-330^{\circ}$ and wind speeds of $1-1.5 \mathrm{~m} \mathrm{~s}^{-1}$ from 2200 to 0800 LT. There was a brief
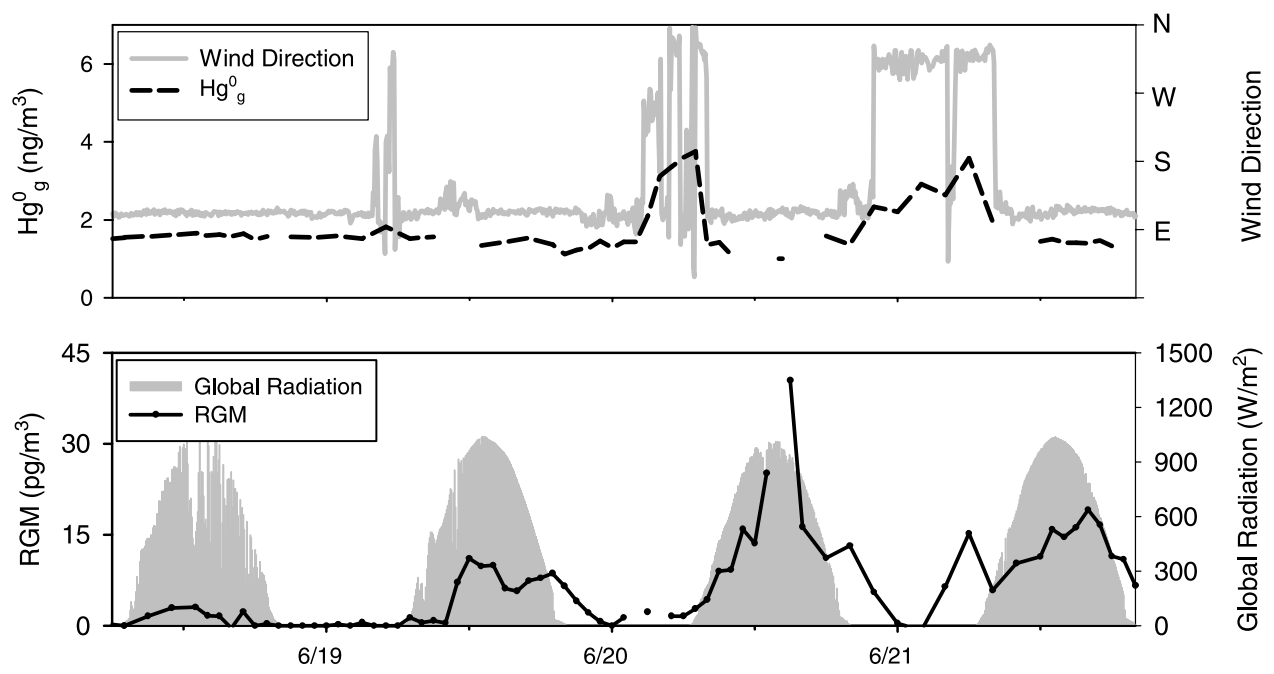

Figure 3. Comparison of elemental gaseous mercury $\left(\mathrm{Hg}_{(g)}^{0}\right)$ and wind direction and reactive gaseous mercury and global radiation for 4 days of the study. 


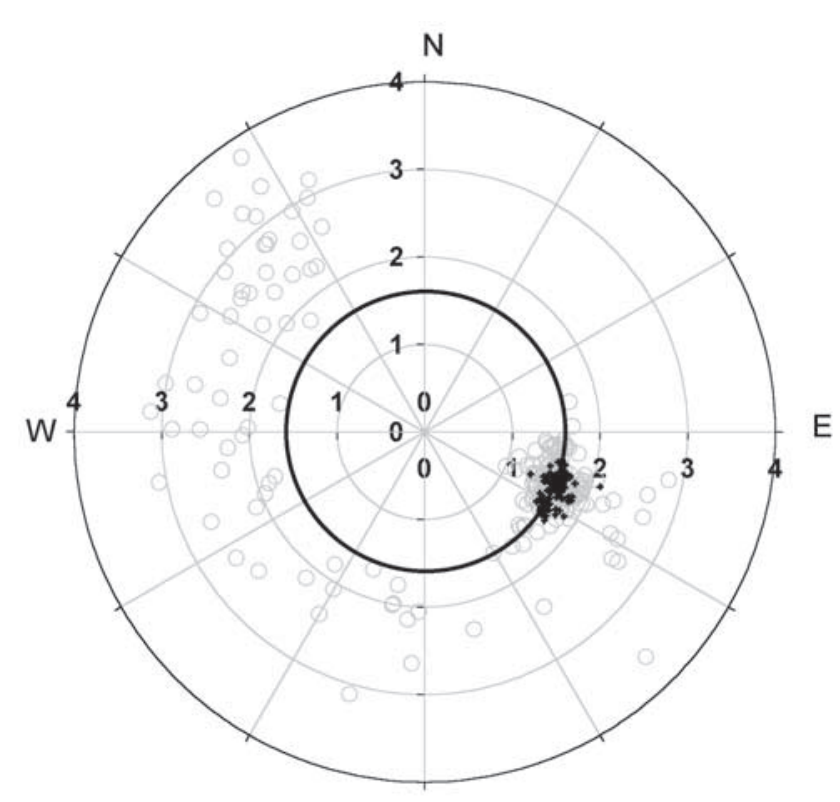

S

$\mathrm{Hg}^{0}{ }_{(\mathrm{g})}$ concentrations during mixed flow conditions

$+\mathrm{Hg}_{(\mathrm{g})}^{0}$ concentrations during marine flow conditions

Figure 4. Variation in hourly averaged $\mathrm{Hg}_{(g)}^{0}$ concentrations $\left(\mathrm{ng} \mathrm{m}^{-3}\right)$ with wind direction. Circles represent concentrations during the mixed conditions, and pluses represent concentrations during the marine conditions. The solid contour marks the mean concentration of $\mathrm{Hg}_{(g)}^{0}$ during the marine conditions of $1.6 \mathrm{ng} \mathrm{m}^{-3}$.

change in direction to east from 0415 to $0450 \mathrm{LT}$, during which $\operatorname{Hg}_{(g)}^{0}$ also dropped in concentration. Throughout the study, higher $\mathrm{Hg}_{(g)}^{0}$ concentrations corresponded to wind directions of westerly or northwesterly, indicating that continental air has characteristically higher $\mathrm{Hg}^{0}$ concentrations than marine air. This is demonstrated in Figure 4, in which $\mathrm{Hg}_{(g)}^{0}$ concentration is plotted as a radial distance in relation to the direction of the wind.

\subsection{Particulate Mercury}

[32] Lamborg et al. [1999] and Mason et al. [2001] have both measured $\mathrm{Hg}_{(p)}$ on cruises on the Atlantic. The first of these was in May and June 1996, by Lamborg et al. [1999] in the South and equatorial Atlantic (Uruguay to Barbados). Total aerosol $\mathrm{Hg}_{(p)}$ (all size ranges) was measured as 1.3$4.8 \mathrm{pg} \mathrm{m}^{-3}(n=10)$. Sampling durations ranged from 17 to 67 hours at a flow rate of $30 \mathrm{~L} \mathrm{~min}^{-1}$ on quartz filters. The cruises by Mason et al. [2001], in the Bermuda area, were in September and December 1999 and March 2000. Total aerosol $\operatorname{Hg}_{(p)}$ was always $<2 \mathrm{pg} \mathrm{m}^{-3}$. Samples were collected on Teflon filters over durations from $\sim 5$ to 12 hours. Flow rates were not reported, but previous measurements by these authors were $<10 \mathrm{~L} \mathrm{~min}{ }^{-1}$ [Sheu and Mason, 2001].

[33] $\mathrm{Hg}_{(p)}$ measured on these Atlantic cruises for total aerosols were less than those for $\mathrm{PM}_{10}$ samples in this study. It is difficult to determine the exact reason, given the small sample sizes for all studies, but there are several possible explanations for the difference. First, the collec- tion methods could be affected by artifacts to different degrees due to variations in filter type, flow rate, duration, aerosol size fraction, and aerosol chemistry. Second, the concentrations could reflect actual variations in $\mathrm{Hg}_{(p)}$ by location. The other measurements were made over the open ocean and may have been less affected by anthropogenic sources or included more recently emitted sea-salt particles. Lastly, contrasting meteorology during the studies would affect what sources impacted the site, relative humidity would affect the amount of water associated with the aerosols, and wind speeds would affect rates of sea-salt emission.

[34] In order to assess the input of sea salt to total $\mathrm{Hg}_{(p)}$, a simple relationship was tested. Assuming no chemical transformations or phase changes during sea-salt formation, the following relationship would be true:

$$
[\mathrm{Hg}]_{\text {ocean }} /\left[\mathrm{Na}^{+}\right]_{\text {ocean }}=[\mathrm{Hg}]_{\text {aerosol }} /\left[\mathrm{Na}^{+}\right]_{\text {aerosol }}
$$

This relation should predict the ambient $\operatorname{Hg}_{(p)}$ concentration if the source of all $\mathrm{Hg}$ in the aerosol is ocean-derived sea salt. A surface grab sample of ocean water $\sim 30 \mathrm{~m}$ off Pompano Beach was analyzed by CVAFS for $\mathrm{Hg}$ and by ion chromatography for major ions. The cations $\mathrm{K}^{+}, \mathrm{Mg}^{2+}$, and $\mathrm{Ca}^{2+}$ were also used in place of $\mathrm{Hg}$ in the above equation. These ratios of major ions in the ocean water were within 1 order of magnitude of their ratio in aerosol during the marine regime, confirming that the equation is a good approximation. Using any of the major cations with this formula predicted a maximum $\mathrm{Hg}_{(p)} \mathrm{PM}_{2.5}$ concentration of $0.0004 \mathrm{pg} \mathrm{m}^{-3}$ for sampling days during the marine regime. On average during this period, the predicted concentration is only $\sim 0.003 \%$ of measured. For the mixed regime, the predicted concentration is $0.004 \%$ of measured.

[35] One potential source of underestimation is that sea salt is formed from the very surface layer of the ocean, which is often more concentrated in pollutants than water at depths of several centimeters [Schneider and Gagosian, 1985]. The concentration of the grab sample taken offshore at Pompano Beach was $0.9 \mathrm{ng} \mathrm{L}^{-1}$, which is similar to that of other Atlantic Ocean samples from various depths [Mason et al., 2001; Mason and Sullivan, 1999; Lamborg et al., 1999]. Studies of the microlayer of Lake Michigan by Cleckner [1995] found enhancements above the bulk water $\mathrm{Hg}$ concentration of up to $\sim 50 \%$. These previous studies suggest that $\mathrm{Hg}$ enhancements in the microlayer could not account for the 4 order of magnitude difference between estimated and measured $\mathrm{Hg}$ concentrations.

[36] The inability to account for aerosol $\mathrm{Hg}$ by ocean water concentrations suggests that another source of $\mathrm{Hg}$ is controlling ambient $\mathrm{Hg}_{(p)}$ concentrations. The most likely explanation is mass transfer of $\mathrm{Hg}_{(g)}^{0}$ or RGM. Owing to high humidities in coastal environments, and their hygroscopic nature, sea-salt particles are expected to have an associated aqueous phase that could facilitate this mass transfer. RGM preferentially partitions into the aqueous phase, as evident by the Henry's law coefficient for $\mathrm{HgCl}_{2(g)}$ $\left(3.7 \times 10^{-5} \mathrm{~Pa}^{3} \mathrm{~mol}^{-1}\right)$. In contrast, the Henry's law coefficient for the less soluble $\mathrm{Hg}_{(g)}^{0}$ is $729 \mathrm{~Pa}^{3} \mathrm{~mol}^{-1}$. Consequently, RGM is expected to partition more rapidly into the sea-salt aerosol. Concentrations of RGM were typically low during the marine period $\left(<7 \mathrm{pg} \mathrm{m}^{-3}\right)$, as 
were $\operatorname{Hg}_{(p)} \mathrm{PM}_{2.5}$ concentrations $\left(<0.8-18 \mathrm{pg} \mathrm{m}^{-3}\right)$. Seasalt aerosol may be an important sink for RGM in the marine boundary layer, significantly reducing ambient RGM concentrations.

[37] Modeling by Hedgecock and Pirrone [2001] suggests that sea-salt aerosol may act as a reaction vessel for oxidizing atmospheric $\mathrm{Hg}$. They hypothesize that $\mathrm{Hg}_{(g)}^{0}$ is transferred to the aqueous phase of sea-salt aerosol and subsequently oxidized to a $\mathrm{Hg}$ (II) species. As the aqueous concentration of $\mathrm{HgCl}_{2(a q)}$ builds up from this oxidation, a fraction of it partitions into the gas phase forming RGM. After reaching equilibrium the initial gas phase concentration $\left(3 \mathrm{n} \mathrm{m}^{-3}\right)$ was depleted by $\sim 10 \%, \mathrm{Hg}_{(a q)}^{0}$ was $2 \times 10^{-7}$

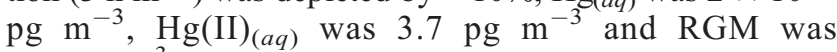
$4.7 \mathrm{pg} \mathrm{m}^{-3}$. The final concentration of total $\mathrm{Hg}_{(p)}$ for their mechanism is less than for this study. Concentrations at Pompano Beach during the marine period for $\mathrm{PM}_{10}$ particles averaged $25 \mathrm{pg} \mathrm{m}^{-3}$, and total $\mathrm{Hg}_{(p)}$ was likely higher. However, this mechanism could explain why $\mathrm{Hg}_{(p)}$ concentrations are enhanced over concentrations in sea salt alone and should be further investigated. If the source of $\mathrm{Hg}$ in the aerosols is $\operatorname{Hg}_{(g)}^{0}$, this mechanism could be an important source of $\mathrm{Hg}$ deposition to oceans and coasts but would not significantly deplete $\operatorname{Hg}_{(g)}^{0}$ over oceans.

[38] The lifetime of sea-salt aerosol can range to up to a few days and is a function of the wind speeds and particle size [Sander and Crutzen, 1996]. Sea-salt penetration onto land is greatest in the first few kilometers but can exceed 50 $\mathrm{km}$ inland [Gustafsson and Franzen, 2000]. In some cases, sea-salt particles may be transported to the free troposphere as well [Patterson et al., 1980]. Aerosols may continue to scavenge $\mathrm{Hg}$ gases throughout their lifetime, as long as they have an associated water phase. Consequently, the effects of $\mathrm{Hg}$ scavenging by sea salt may be globally important. Further investigations are needed to determine the effect of this process on ambient $\mathrm{Hg}$ concentrations and deposition of $\mathrm{Hg}$ to oceans and coasts.

\subsection{Reactive Gaseous Mercury}

[39] Emissions testing and laboratory studies have shown that RGM can be emitted directly from sources as well as formed by chemical oxidation in the atmosphere. RGM has been measured in emissions from several source types, including incinerators, coal-fired power plants, and chloralkali facilities [Dvonch et al., 1999; Carpi, 1997] (M. S. Landis et al., Divalent inorganic reactive gaseous mercury emissions from a mercury cell chlor-alkali plant and its impact on near field atmospheric dry deposition, submitted to Atmospheric Environment, 2003). Oxidants previously investigated for $\mathrm{RGM}$ production in kinetics experiments include the gases $\mathrm{O}_{3}, \mathrm{H}_{2} \mathrm{O}_{2}, \mathrm{NO}_{3}$, $\mathrm{OH}$, $\mathrm{BrO}, \mathrm{Br}_{2}, \mathrm{Br}, \mathrm{ClO}$, $\mathrm{Cl}_{2}$, and $\mathrm{Cl} \cdot$ [Tokos et al., 1998; Sommar et al., 2001, 1997; Spicer et al., 2002], and possibly $\mathrm{HO}_{2}{ }^{\circ}$ [Lin and Pehkonen, 1999]. Many of these species are formed via photochemical reactions, which suggests that RGM production could also have a diurnal cycle. The source of RGM at a given location may therefore be transport from an emission source or local formation by atmospheric chemistry. To investigate the potential sources of RGM to our site, comparisons were made of RGM concentrations by wind direction, solar radiation, $\mathrm{Hg}_{(\mathrm{g})}^{0}$, and $\mathrm{O}_{3}$. Figure 3 shows these measurements for 4 days of the study.
Table 3. Estimated Rates of Production of RGM from Oxidation of $\mathrm{Hg}_{(g)}^{0}$ With Several Reactants ${ }^{\mathrm{a}}$

\begin{tabular}{|c|c|c|c|}
\hline Reactant & $\begin{array}{c}\text { Rate of RGM } \\
\text { Production, } \\
\text { molecules } \\
\mathrm{cm}^{-3} \mathrm{~s}^{-1} \\
\end{array}$ & $\begin{array}{c}\text { Reaction Rate } \\
\text { Reference }\end{array}$ & $\begin{array}{c}\text { Concentration } \\
\text { Reference }\end{array}$ \\
\hline $\mathrm{O}_{3}$ & 5.0 & [Spicer et al., 2002] & this study \\
\hline $\mathrm{OH}^{-}$ & & [Sommar et al., 2001] & [Xu et al., 2001] \\
\hline $\mathrm{NO}_{3} \cdot$ & $0-120$ & [Sommar et al., 1997] & [Xu et al., 2001] \\
\hline $\mathrm{H}_{2} \mathrm{O}_{2}$ & $0.05-0.2$ & [Tokos et al., 1998] & [Xu et al., 2001] \\
\hline $\mathrm{BrO}^{\circ}$ & $76-160$ & [Spicer et al., 2002] & [Iverfeldt et al., 2001] \\
\hline $\mathrm{Br}_{2}$ & 0.01 & [Spicer et al., 2002] & [Impey et al., 1997] \\
\hline $\mathrm{Br}$ & $38-6100$ & [Spicer et al., 2002] & [Barrie et al., 1994] \\
\hline $\mathrm{ClC}$ & & [Spicer et al., 2002] & [Stutz et al., 1999] \\
\hline $\mathrm{Cl}_{2}$ & $0.1-0.8$ & [Spicer et al., 2002] & [Keene et al., 1993] \\
\hline $\mathrm{Cl}$ & 0.3 & [Spicer et al., 2002] & [Maben et al., 1995] \\
\hline
\end{tabular}

${ }^{\mathrm{a}}$ For comparison, the maximum rate of RGM increase measured in this study is 9.6 molecules $\mathrm{cm}^{-3} \mathrm{~s}^{-1}$.

[40] As discussed previously, RGM typically exhibited a diurnal pattern, peaking between 1100 and 1700 LT (although many of the marine-dominated samples were below the MDL). During the study, global radiation reached its maximum between 1300 and 1400 LT. Additionally some peaks in RGM corresponded to peaks in $\operatorname{Hg}_{(g)}^{0}$ and changes in wind direction, suggesting $\mathrm{RGM}$ and $\mathrm{Hg}_{(g)}^{0}$ were transported from a source within Florida.

[41] During the mixed period the amplitude of the diurnal peaks was higher than during the marine period, suggesting that either daytime meteorological conditions lead to enhanced transport from anthropogenic sources or photochemical reactions were creating RGM in situ. Ozone was sometimes higher during the mixed than during the marine regime, although diurnal peaks were broader than for RGM, suggesting that ozone alone could not be producing the daytime RGM peaks. Hydroxyl radical has been found to be higher over continents than the remote ocean due partially to anthropogenic emissions over land [Seinfeld and Pandis, 1998] and could be a source of RGM production. Bromine monoxide, $\mathrm{BrO}$, which has been implicated in the Arctic $\mathrm{Hg}_{(g)}^{0}$ oxidation, may actually have higher concentrations during the mixed than during the marine regime for this study. This is because $\mathrm{BrO}$ is formed by reaction of $\mathrm{Br}$ with $\mathrm{O}_{3}$ [Seinfeld and Pandis, 1998], and $\mathrm{O}_{3}$ was generally higher in concentration during the mixed period. Chorine monoxide, $\mathrm{ClO}$, which is similar in reactivity to $\mathrm{BrO}$, may also be important in the $\mathrm{Hg}$ chemistry of temperate and tropical coastal regions.

[42] To evaluate the importance of these reactants during this study, production rates of RGM were calculated for each oxidant, using published reaction rates where available (Table 3). The $\mathrm{O}_{3}$ concentrations measured in this study were used for the calculation of the $\mathrm{O}_{3}$ and $\mathrm{Hg}_{(\mathrm{g})}^{0}$ reaction rate. As an estimate, the $\mathrm{BrO}^{-}$and $\mathrm{ClO}^{\circ}$ concentrations used were for the west coast of Ireland [Iverfeldt et al., 2001; Stutz et al., 1999]. Concentrations of $\mathrm{Cl}_{2}$ and $\mathrm{Cl}$ used were measured near our Florida sampling site [Keene et al., 1993; Maben et al., 1995]. Extensive measurements of $\mathrm{Br}^{2}$ and $\mathrm{Br}$ have not been made, so concentrations were estimated to be at the lower end of those measured in the Arctic [Impey et al., 1997; Barrie et al., 1994]. Concentrations of $\mathrm{OH}^{-}, \mathrm{NO}_{3}$, and $\mathrm{H}_{2} \mathrm{O}_{2}$ were estimated using the Community MultiScale Air Quality Modeling System developed by the EPA [Xu et 
al., 2001]. The maximum and minimum concentrations from hourly model results of 11-12 June 2000 were used to calculate a range in production rates.

[43] The fastest rate of increase in RGM measured during the study was 9.6 molecules $\mathrm{cm}^{-3} \mathrm{~s}^{-1}$, on 20 June 202000 . On this day the concentration of RGM was $13.6 \mathrm{pg} \mathrm{m}^{-3}$ from 1200 to $1300 \mathrm{LT}$, and increased to 25.2 from 1300 to 1400 LT. The winds were from the southeast at $\sim 2 \mathrm{~m} \mathrm{~s}^{-1}$ and skies were clear. During the previous night, winds were light $\left(<1 \mathrm{~m} \mathrm{~s}^{-1}\right)$ and from the west and northwest. Meteorological simulations using the Mesoscale Model [Dudhia, 1993] indicate that sea breeze conditions brought marine flow to the site on this day. There was convergence inland over the Florida peninsula, which caused updrafts and a return flow aloft back toward the Atlantic. The modeling indicates that from 19 to 21 June the meteorology was very dynamic with mixing of marine and continental air.

[44] Although maximum production rates of RGM with $\mathrm{NO}_{3} \cdot$ were estimated to be over 100 molecules $\mathrm{cm}^{-3} \mathrm{~s}^{-1}$ (Table 3 ), $\mathrm{NO}_{3}$ concentrations generally peak at night and therefore could not have caused the observed daytime RGM maximums. Similarly, limited measurements of $\mathrm{Cl}_{2}$ suggest that this halogen increases in concentration at night [Keene et al., 1993] and therefore cannot solely be responsible for the RGM observations. Of the oxidants in Table 3, the most likely to have been significant in this study are $\mathrm{OH}^{\circ}, \mathrm{BrO}$, and $\mathrm{Br}$. Reactions not yet understood or investigated, such as many possible heterogeneous reactions, may also be significant.

[45] Meteorology can also explain the fluctuations in RGM concentrations, with diurnal changes in the marine boundary layer, and the potential for downward transport of RGM from the free troposphere under subsidence conditions. These influences should also be investigated in more detail.

\section{Conclusions}

[46] The lowest $\mathrm{Hg}$ concentrations measured during the study were associated with "clean" marine flow, suggesting that the marine boundary layer is not a large source of $\mathrm{Hg}$ on an event basis relative to sources within Florida. This does not necessarily mean that oxidation of $\operatorname{Hg}_{(g)}^{0}$ by reactive halogen species is not fast but that the net production rate, including removal by dry deposition and mass transfer to aerosols, does not result in significantly elevated RGM concentrations. If the rates of oxidation by halogens, dry deposition, and transfer to sea-salt aerosol are high, this may be a key multistep process for transfer of atmospheric $\mathrm{Hg}$ to oceans. Additionally, on an annual basis some coastal regions could receive the majority of their $\mathrm{Hg}$ deposition from the MBL if transport from the ocean dominates meteorological conditions.

[47] $\mathrm{Hg}_{(p)}$ concentrations during "clean" marine flow could not be explained by sea-salt contributions of $\mathrm{Hg}$ alone. It is therefore deduced that a mass transfer of $\mathrm{Hg}_{(g)}^{0}$ or RGM to existing aerosols comprises most of the $\mathrm{Hg}_{(p)}$ concentration. RGM, which exhibited a diurnal behavior, had highest peaks during mixed conditions when urban air mixed with marine air was transported to the site. The high RGM concentrations are hypothesized to be caused by in situ oxidation of $\mathrm{Hg}_{(\mathrm{g})}^{0}$ by $\mathrm{OH}, \mathrm{BrO}, \mathrm{Br}$, or another unknown oxidant, all of which are likely to be elevated by anthropogenic and continental emissions. This study reveals that although concentrations of $\mathrm{Hg}$ species were often quite low in the marine boundary layer and coastal environment in June, $\mathrm{Hg}$ cycling is very complex and dynamic in these regions.

[48] Acknowledgments. Research in Florida was funded by the Florida Department of Environmental Protection, the EPA National Exposure Research Laboratory, and the EPA Science to Achieve Results Graduate Fellowship Program. We thank Jim Barres and Kelly Quintal of the University of Michigan, who provided assistance with field sampling, Khalid Al-wali, who modeled meteorology, and Kenneth P. Larson (Broward County Department of Planning and Environmental Protection), Robert K. Stevens, and Thomas Atkeson (Florida Department of Environment Protection), who provided logistical support. We also appreciated the insightful comments of an anonymous reviewer, which improved the final version of this manuscript. This work has been funded wholly or in part by the U.S. Environmental Protection Agency Office of Research and Development. It has been subjected to agency review and approved for publication. Mention of trade names or commercial products does not constitute an endorsement or recommendation for use.

\section{References}

Ahrens, C. D., Meteorology Today: An Introduction to Weather, Climate, and the Environment, West Publ., Minneapolis, Minn., 1994.

Barrie, L. A., S.-M. Li, D. L. Toom, S. Landsberger, and W. Sturges, Lower tropospheric measurements of halogens, nitrates, and sulphur oxides during Polar Sunrise Experiment 1992, J. Geophys. Res., 99, 25,45325,467, 1994.

Birch, M. E., and R. A. Cary, Environmental carbon-based method for monitoring occupational exposures to particulate diesel exhaust, Aerosol Sci. Technol., 25, 221-241, 1996.

Carpi, A., Mercury from combustion sources: A review of the chemical species emitted and their transport in the atmosphere, Water Air Soil Pollut., 98, 241-254, 1997.

Cleckner, L. B., Atmospheric pollutants as a source of trace metals to the microlayer of southern Lake Michigan, Ph.D. thesis, U. of Michigan, Ann Arbor, 1995.

Cody, R. P., and J. K. Smith, Applied Statistics and the SAS Programming Language, 4th ed. Prentice-Hall, Old Tappan, N. J., 1997.

Dudhia, J., A nonhydrostatic version of the Penn State/NCAR mesoscale model: Validation tests and simulation of an Atlantic cyclone and cold front, Mon. Weather Rev., 121, 1493-1513, 1993.

Dvonch, J. T., J. R. Graney, F. J. Marsik, G. J. Keeler, and R. K. Stevens, An investigation of source-receptor relationships for mercury in south Florida using event precipitation data, Sci. Total Environ., 213, 95108,1998

Dvonch, J. T., J. R. Graney, G. J. Keeler, and R. K. Stevens, Use of elemental tracers to source apportion mercury in south Florida precipitation, Environ. Sci. Technol., 33, 4522-4527, 1999.

Dvonch, J. T., G. J. Keeler, M. M. Lynam, F. J. Marsik, and J. A. Barres, Real-time observations of the production of reactive gaseous mercury (RGM) in ambient air, Proceedings of Specialty Conference on Mercury Emissions: Fate, Effects and Control, pp. 125-132, Air and Waste Manage. Assoc., Chicago, Ill., 21-23 Aug., 2001.

Environmental Protection Agency (EPA), Mercury study report to Congress, Rep. EPA 452/R-97-0003, Washington, D. C., 1998.

Guentzel, J. L., W. M. Landing, G. A. Gill, and C. D. Pollman, Atmospheric deposition of mercury in Florida-The FAMS Project (19921994), Water Air Soil Pollut., 80, 393-402, 1995.

Gustafsson, M. E. R., and L. G. Franzen, Inland transport of marine aerosols in southern Sweden, Atmos. Environ., 34, 313-325, 2000.

Hedgecock, I. M., and N. Pirrone, Mercury and photochemistry in the marine boundary layer-Modeling studies suggest the in situ production of reactive gas phase mercury, Atmos. Environ., 35, 3055-3062, 2001.

Impey, G. A., P. B. Shepson, D. R. Hastie, L. A. Barrie, and K. G. Anlauf, Measurements of photolyzable chlorine and bromine during the Polar Sunrise Experiment 1995, J. Geophys. Res., 102, 16,005$16,010,1997$.

Iverfeldt, A., J. Munthe, I. Waengberg, R. Ebinghaus, and G. Petersen, The role of northern marginal seas in the European Mercury cycle-Implications for policy making, paper presented at 6th International Conference on Mercury as a Global Pollutant, Minamata, Japan, 2001.

Keeler, G. J., J. D. Spengler, and R. A. Castillo, Acid aerosol measurements at a suburban Connecticut site, Atmos. Environ., 25, 681-690, 1991. 
Keene, W. C., J. R. Maben, A. A. P. Pszenny, and J. N. Galloway, Measurement technique for inorganic chlorine gases in the marine boundary layer, Environ. Sci. Technol., 27, 866-874, 1993.

Lamborg, C. H., K. R. Rolfhus, W. F. Fitzgerald, and G. Kim, The atmospheric cycling and air-sea exchange of mercury species in the South and Equatorial Atlantic Ocean, Deep Sea Res., Part II, 46, 957-977, 1999.

Landing, W. M., J. J. Perry, J. L. Guentzel, G. A. Gill, and C. D. Pollman, Relationships between the atmospheric deposition of trace-elements, major ions, and mercury in Florida-The FAMS Project (1992-1993), Water Air Soil Pollut., 80, 343-352, 1995.

Landis, M. S., and J. G. Keeler, Critical evaluation of a modified automatic wet-only precipitation collector for mercury and trace element determinations, Environ. Sci. Technol., 31, 2610-2615, 1997.

Landis, M. S., R. K. Stevens, F. Schadelick, and E. M. Prestbo, Development and characterization of an annular denuder methodology for the measurement of ambient (divalent) inorganic reactive gaseous mercury in ambient air, Environ. Sci. Technol., 36, 3000-3009, 2002.

Lin, C. J., and S. O. Pehkonen, The chemistry of atmospheric mercury: A review, Atmos. Environ., 33, 2067-2079, 1999.

Lindberg, S. E., S. Brooks, C. J. Lin, K. J. Scott, M. S. Landis, R. K. Stevens, M. Goodsite, and A. Richter, Dynamic oxidation of gaseous mercury in the Arctic troposphere at polar sunrise, Environ. Sci. Technol., 36, 3000-3009, 2002.

Maben, J. R., W. C. Keene, A. A. P. Pszenny, and J. N. Galloway, Volatile inorganic $\mathrm{Cl}$ in surface air over eastern North America, Geophys. Res. Lett., 22, 3513-3516, 1995.

Malcolm, E. G., The effect of mercury speciation and meteorological processing on concentrations, transport and deposition of atmospheric mercury, Ph.D. thesis, U. of Michigan, Ann Arbor, 2002.

Malcolm, E. G., and J. G. Keeler, Measurements of mercury in dew: Atmospheric removal of mercury species to a water surface, Environ. Sci. Technol., 36, 2815-2821, 2002.

Mason, R. P., and K. A. Sullivan, The distribution and speciation of mercury in the South and Equatorial Atlantic, Deep Sea Res., Part II, 46, 937-956, 1999

Mason, R. P., N. M. Lawson, and G. R. Sheu, Mercury in the Atlantic Ocean: Factors controlling air-sea exchange of mercury and its distribution in the upper waters, Deep Sea Res., Part II, 48, 2829-2853, 2001

Munthe, J., R. Ebinghaus, K. Gardfeldt, A. Iverfeldt, K. Larjava, O. Lindqvist, G. Petersen, V. Siemens, J. Sommar, and I. Wangberg, Mercury species over Europe, paper presented at 6th International Conference on Mercury as a Global Pollutant, Minamata, Japan, 2001.

Patterson, E. M., C. S. Kiang, A. C. Delany, A. F. Wartburg, A. C. D. Leslie, and B. J. Huebert, Global measurements of aerosols in remote contintental and marine regions: Concentrations, size distributions, and optical properties, J. Geophys. Res., 85, 7361-7376, 1980.

Perrino, C., and M. Gherardi, Optimization of the coating layer for the measurement of ammonia by diffusion denuders, Atmos. Environ., 33 4579-4587, 1999

Pinto, J. P., R. K. Stevens, R. D. Willis, R. Kellog, Y. Mamane, J. Novak, J. Santrach, I. Benes, J. Lenicek, and V. Bures, Czeck air quality and monitoring study, Environ. Sci. Technol., 32, 843-854, 1998.

Prestbo, E. M., and N. S. Bloom, Determination of atmospheric gaseous $\mathrm{HG}$ (ii) at the $\mathrm{pg} / \mathrm{m}^{3}$ level by collection onto cation exchange membranes, followed by dual amalgamation/cold vapor atomic fluorescence spectro- metry, paper presented at 4th International Conference on Mercury as a Global Pollutant, Hamburg, Germany, 4-8 August, 1996.

Sander, R., and P. Crutzen, Model study indicating halogen activation and ozone destruction in polluted air masses transported to the sea, J. Geophys. Res., 101, 9121-9138, 1996.

Schneider, J. K., and R. B. Gagosian, Particle size distribution of lipids in aerosols off the coast of Peru, J. Geophys. Res., 90, 7889-7898, 1985.

Schroeder, W. H., K. G. Anlauf, L. A. Barrie, J. Y. Lu, A. Steffen, D. R. Schneeberger, and T. Berg, Arctic springtime depletion of mercury, Nature, 394, 331-332, 1998.

Seinfeld, J. H., and S. N. Pandis, Atmospheric Chemistry and Physics: From Air Pollution to Climate Change, Wiley-Interscience, New York, 1998.

Sheu, G. R., and R. P. Mason, An examination of methods for the measurements of reactive gaseous mercury in the atmosphere, Environ. Sci. Technol., 35, 1209-1216, 2001.

Sommar, J., M. Hallquist, E. Ljungstrom, and O. Lindqvist, On the gas phase reactions between volatile biogenic mercury species and the nitrate radical, J. Atmos. Chem., 27, 233-247, 1997.

Sommar, J., K. Gardfeldt, D. Stromberg, and X. B. Feng, A kinetic study of the gas-phase reaction between the hydroxyl radical and atomic mercury, Atmos. Environ., 35, 3049-3054, 2001

Spicer, C. W., J. Satola, A. A. Abbgy, R. A. Plastridge, and K. A. Cowen, Kinetics of gas-phase elemental mercury reactions with halogen species, ozone, and nitrate radical under atmospheric conditions, prepared report, Fla. Dep. of Environ. Prot., Tallahassee, 2002.

Sprovieri, F., N. Pirrone, I. M. Hedgecock, M. S. Landis, and R. K. Stevens, Intensive atmospheric mercury measurements at Terra Nova Bay in Antarctica during November and December 2000, J. Geophys. Res., 107(D23), 4722, doi:10.1029/2002JD002057, 2002.

Stutz, J., K. Hebestreit, B. Alicke, and U. Platt, Chemistry of halogen oxides in the troposphere: Comparison of model calculations with recent field data, J. Atmos. Chem., 34, 65-85, 1999.

Temme, C., J. W. Einax, R. Ebinghaus, and W. H. Schroeder, Measurements of atmospheric mercury species at a coastal site in the Antarctic and over the South Atlantic Ocean during polar sunrise, Environ. Sci. Technol., 37, 22-31, 2003

Tokos, J. J. S., B. Hall, J. A. Calhoun, and E. M. Prestbo, Homogeneous gas-phase reaction of $\mathrm{Hg}^{0}$ with $\mathrm{H}_{2} \mathrm{O}_{2}, \mathrm{O}_{3}, \mathrm{CH}_{3} \mathrm{I}$, and $\left(\mathrm{CH}_{3}\right)_{2} \mathrm{~S}$ : Implications for atmospheric $\mathrm{Hg}$ cycling, Atmos. Environ., 32, 823-827, 1998.

Volpe, C., M. Wahlen, A. A. P. Pszenny, and A. J. Spivack, Chlorine isotopic composition of marine aerosols: Implications for the release of reactive chlorine and $\mathrm{HCl}$ cycling rates, Geophys. Res. Lett., 25, $3831-$ 3834, 1998.

Xu, X., G. J. Keeler, S. Silmann, K. I. Al-Wali, A simulation study of the influence of local and regional atmospheric mercury sources on mercury wet deposition in south Florida, paper presented at 6th International Conference on Mercury as a Global Pollutant, Minamata, Japan, 2001.

G. J. Keeler, Air Quality Laboratory, University of Michigan, Ann Arbor, MI 48109, USA. (jkeeler@umich.edu)

M. S. Landis, Office of Research and Development, Environmental Protection Agency, Research Triangle Park, NC 27711, USA. (landis. mathew@epa.gov)

E. G. Malcolm, Department of Geosciences, Princeton University, Princeton, N. J., 08540, USA. (emalcolm@princeton.edu) 